\title{
Malaysian Counselors' Self-Efficacy: Implication for Career Counseling
}

\author{
Ab Rahim Bakar (Corresponding author) \\ University Putra Malaysia \\ 43400 Serdang, Selangor, Malaysia
}

Tel: 60-3-8946-8110 E-mail: abrahimbakar@yahoo.com

\author{
Noor Syamilah Zakaria \\ University Putra Malaysia \\ 43400 Serdang, Selangor, Malaysia
}

Tel: 60-3-8946-8128 E-mail: syamilah@putra.upm.edu.my

\author{
Shamsiah Mohamed \\ Universiti Putra Malaysia \\ 43400 Serdang, Selangor, Malaysia \\ Tel: 60-3-8946-7854 E-mail: shamsiah@math.upm.edu.my
}

Received: February 10, $2011 \quad$ Accepted: July 18, $2011 \quad$ doi:10.5539/ijbm.v6n9p141

\begin{abstract}
The present study was intended to measure Malaysian counselors' self-efficacy. The finding shows that Malaysian school counselors have high self-efficacy. Self-efficacy correlated significantly with work experience as a counselor. The study also shows that counselors with postgraduate education are more effacious than their counterparts who have an undergraduate degree only. Counselors' self-efficacy does not differ as a function of gender and program of study. However, what is important is their experiences and advance education.
\end{abstract}

Keywords: Malaysian counselor, Counselor's self-efficacy, Counseling competencies, Career counseling

\section{Introduction}

As an adolescent, the most crucial decision one has to make concerns career and educational decision. Adolescents have to make decisions related to further education and job selection. The decision has to be made with or without helps from significant others such as parents, classroom teachers, or counselors. Luckily, in schools there are counselors who can help these young people on his or her journey into the future. School career counselor is the certified person to accompany the young person to his/her journey towards occupational development. A school counselor shoulders a heavy responsibility to ensure that students make right educational and career decisions. School counselors perform a rather multiple role job, demanding special competencies acquired via formal education, specialized training and personal development training.

\section{Self-efficacy and its' roles}

One major problem that the field of career guidance is facing concerns the misunderstanding of the key terms and therefore their misuse by the trained career counselors (Herr, Cramer, \& Niles, 2004; Niles \& Karajic, 2008). This note might mean that the career counselors may not be aware of the full range of competencies needed for the implementation of their job. They have to have certain level of competencies in counseling in order for them to provide effective counseling services to students. The belief about ones' abilities to perform to successfully perform a given task to accomplish specific goals is known as self-efficacy (Lent \& Hackett, 1987). Social Cognitive theory (Bandura, 1977a, 1977b, 1986a, 1996) posits that self-efficacy is an important component of career performance and preparation. Bandura (1995) found that persons with higher levels of self-efficacy beliefs set higher goals and exhibit stronger commitment, motivation, perseverance, and resiliency in achieving those goals. Counselor should have all those mentioned by Bandura because their responsibility is so important that bring an impact of the future of students. For instance, research has shown a consistent relationship between academic achievement and school counseling program efforts (Brigman \& Campbell, 2003; Fitch \& Marshall, 
2004; Lapan, Gysbers, \& Petroski, 2001; Legum \& Hoare, 2004; Sink \& Stroh, 2003; Webb, Brigman, \& Campbell, 2005). Larson and Daniels (1998) state that counselor self-efficacy beliefs are the primary determinant of effective counseling action. As stated by Bandura (1996), unless people believe they can produce desired effects by their actions they have little incentive to act.

There are many activities, which, if done well, guarantee valued outcomes, but people who doubt they can do what it takes to succeed do not pursue them. A low sense of efficacy can thus nullify the motivating potential of alluring outcomes. Conversely, firm belief in one's efficacy can sustain efforts over prolonged periods in the face of uncertain or repeated negative outcomes. Counselor self-efficacy can be described as a counselor's beliefs or judgments about his or her capabilities to effectively counsel a client (Larson, Suzuki, Gilespie, Potenza, Bechtel, \& Toulouse, 1992). Larson (1998) defined counselor self-efficacy as one's beliefs or judgments about one's capabilities to effectively counsel a client in the near future. To have this belief, school counselors need to feel confident that they are performing duties for which they have received sufficient training and are supported in carrying out expectations (Clark, 2006). Larson \& Daniels (1998) said that Effective counselors are expected to have the ability to adapt and improvise multiple counseling skills in order to manage the fluctuating and changing circumstances within the counseling session. Counseling self-efficacy (CSE) describes a counselor's judgment about his or her own ability to effectively counsel a client (Daniels \& Larson, 2001)

Counselor self-efficacy can be influenced by graduate training program curricula, participation in an in-service/workshop, counseling experience with specific issues, and years of experience (Larson \& Daniels, 1998; Lent, Hill, \&Hoffman, 2003; Melchert, Hays, Wiljanen, \& Kolocek, 1996; Murphy, 2004). Experience was found to contribute to self-efficacy as reported by Melchert, Hays, Wilijnen, \& Kolocek (1996) and. Larson et al. (1992). Depth and breadth of counseling experience seem to have an impact on the strength of counseling self-efficacy. For example, master's level counselors and counseling psychologists reported higher counseling self-efficacy as compared to bachelor's level counselor trainees. Moreover, practitioners with counseling experience were found to exhibit stronger percepts of counseling efficacy than those who had no or little counseling experience (Larson et al., 1992).

Counseling program is an important feature of a school. Many positive results have been documented when schools have complete counseling program. Examples are studies by Lapan, Gysbers, \& Petroski (2001) and Steen \& Kaffenberger (2007). In a study on elementary school students' participation in-group counseling, Steen \& Kaffenberger (2007) found that students improve both behaviorally and academically. Similarly, in a study using $7^{\text {th }}$ grade students who attended schools with more fully implemented school counseling programs, Lapan, Gysbers, \& Petroski (2001) reported that those students have a better relationships with teachers, obtained better grades, and display a higher satisfaction with the quality of education.

Self-efficacy is an important construct that has to be taken seriously. Bandura $(1986,1995)$ has said that that people with higher levels of self-efficacy in a particular area of their behavior set higher goals; exhibit stronger commitment, motivation, resilience, and perseverance; and are therefore more likely to meet their goals. According to Bodenhorn et al. (2010), it seems plausible that school counselors with high levels of self-efficacy might affect their students in more effective ways than those with lower levels of school counselor self-efficacy. Counselors who possess stronger versus weaker CSE beliefs (and at least adequate levels of counseling ability) may likely to generate more helpful counseling responses, to persist longer and expend more effort when encountering clinical impasses, and to appear more poised during sessions. In addition to such clinical possibilities, CSE has been assumed relevant to the process of trainees' own career development, for example, helping to determine their interest in, and desire to perform, counseling as a central part of their work lives (Hepnerm O'Brien, Hinkleman, \& Flores, 1996). Counselor self-efficacy may be a critical factor in counseling performance, adopting transitions, and persistence (Larson \& Daniels, 1998). A high level of SE correlates with intensive pursuit of desirable goals. A person with such a level of SE would be more likely to view anxiety as challenging, to set realistic moderately challenging goals and to have thoughts that are self-aiding (Larson \& Daniels, 1998). Counselors' self-efficacy is such an important construct that need investigation, but reviews of the literature produces little evidence showing that it has been widely investigated in the counseling profession. To date, Diane M. Clark (2006) indicate that there has been little research concerning self-efficacy and school counselors. Thus, the authors felt that counselors self-efficacy among school counselors in Malaysia, specifically warrants an investigation. This is to ensure that effective career counseling services are given so student are helped in their preparation for entrance into the world of work or for further education.

\section{Objectives of the study}

The study was undertaken to evaluate Malaysian school counselor self-efficacy in carrying their duties as school counselors. Specifically, the study intended to:

1. Compare counseling self-efficacy between male and female school counselors

2. Compare counseling efficacy between counselors based on level of education

3. Compare counseling efficacy between counselors based on their degree major 
4. Determine the relationship between counseling self-efficacy and counseling experience

\section{Research Procedure}

\subsection{Participants}

There are 2237 secondary schools in Malaysia with a student population of 2,326,297. Approximately 74,000 teachers and 4000 counselors are employed at the secondary level. As of July 2009, 1749 counselors are registered with the board of counselors and of those, 1219 are licensed. For the present study, a total of 500 counselors were randomly chosen to participate.

\subsection{Data Collection}

Questionnaires were mailed to all the selected counselors and they were requested to return the questionnaire using a self-addressed stamped envelope in two weeks time. Initially, a total of 500 school counselors were mailed the questionnaires. However, only 443 questionnaires were useable, as some of the samples did not return the questionnaires. Some were returned as incomplete questionnaires and were discarded.

\subsection{Instrument}

Data were gathered using an instrument developed by the researchers based on the review of literature and roles and responsibilities of Malaysian school counselors. It consists of two sections: the demographic section and self-efficacy section. Counselors' self-efficacy was measured using an instrument consisting of 20 items. The items were general statements asking counselors to indicate their level of confident in carrying their duties as counselors. These statements were adapted from the article Career Counseling Competencies revised version 1997 by National Career Development Association (NCDA) and job specifications of counselors in Malaysian schools. Initially we created 34 items to measure counselors' self-efficacy. Based on the results of a pilot test, some of the items were removed because of their low correlation with the total item. There are items that correlated negatively with total items. These two conditions indicate that those items do not contribute to the measurement and therefore were removed. Counselors were requested to indicate their confidence in carrying duties as counselors using a 5-point Likert scale ranging from not confident at all (1) to very confident (5). Higher scores indicate considerable confidence in one's ability to perform career counseling. The reliability estimate of self-efficacy instrument as ascertained using Cronbach Alpha was 0.96.

\section{Results}

Five hundred school counselors were randomly selected to participate in the study. However, data analysis was done based on 443 usable questionnaires. The participants of the present study are composed of $43.9 \%$ male and $56.1 \%$ female school counselors. Their ages ranged between 24 and 55 years old with a mean of 38.48 years (SD. $=7.78$ years). About $82 \%$ of them are holders of a bachelor's degree and $15.8 \%$ are holders of post-graduate degrees. For those with a bachelor's degree, the majority (75\%) majored in counseling. About $14 \%$ were in other field of studies. Their experiences as school counselors ranged between 1 to 22 years with a mean of 6.34 years (SD. $=3.47$ years). Majority of the counselors who participated in the study worked in schools located in rural areas $(54.2 \%), 20 \%$ of them worked in schools located in urban areas, and $24.4 \%$ worked in schools located in small town areas. They worked in schools consisting of about 450-2892 students. The mean number of students was $1225(\mathrm{SD} .=521)$. In Malaysia, counselors are also trained to teach. While their undergraduate major is guidance and counseling, they also have to have a minor. This is to enable them to teach while in schools. The findings showed that $27.5 \%$ of the counselors teach and $70.4 \%$ of them perform the counseling job alone. The number of counselors in schools ranged between one and five persons with the majority of the schools having two counselors $(43.1 \%)$ and about $26 \%$ of the schools having 3 counselors, and $20.3 \%$ of the schools having only one counselor.

Counselors see themselves positively in their task of helping students (Table 2). The mean score for their self-efficacy was 3.98 (SD. $=0.59$ ). Almost $72 \%$ of them were highly effacious (mean score of $>3.68$ ), approximately $27 \%$ were moderate (mean score $2.37-3.67$ ), and about bout $1 \%$ believed they did not have the capability of performing counseling jobs. A t-test was conducted to compare counseling self-efficacy of male and female school counselors. Although male school counselor obtained a higher mean score $(\mathrm{M}=4.03, \mathrm{Sd} .=$ $0.53)$ than female school counselors $(\mathrm{M}=3.94, \mathrm{SD} .=0.62)$, the difference was not significant $[\mathrm{t}(437)=1.61$; $\mathrm{p}=0.11]$. Counselors with post-graduate degrees obtained higher mean scores than counselors with degree at undergraduate level only. The difference was highly significant [t (429) $=3.19, \mathrm{P}=.002]$. Counselors self-efficacy did not differ as a function of area of studies $(t=-.109, p>.05)$ There was a significant correlation between counseling-efficacy and counselors age $(\mathrm{r}=.137 ; \mathrm{p}=.004)$. A significant correlation was also detected between counseling self-efficacy and experience as a counselor $(\mathrm{r}=.195 ; \mathrm{p}=.000)$

\section{Discussion and Conclusion}

Self-efficacy is an important construct that needs to be investigated among schools counselors. Even with the scarcity of literature on counselors' self-efficacy, but based on teacher sense of efficacy one can conclude that self-efficacy is not to be ignored if counselors are to trive in the profession and to provide excellent services to their clients, their students. Bandura (1997) indicated that individuals with a stronger sense of perceived 
self-efficacy experience low stress in threatening or taxing situations, and experience situations as less stressful owing to their belief in their ability to cope. In teaching, for instance, Gibson and Dembo (1984) argue that teachers with a high sense of instruction efficacy believe that unmotivated students can be taught, given the extra effort and appropriate techniques; that family support can be enlisted; and that negative community influences can be overcome through effective teaching. We believe that school counselors will be able to tackle problems and issues related to counseling and guiding students if they have high sense of efficacy.

According to (Fitch, Newby, Ballestero, \& Marshall, 2001; Kuranz, 2002; Pérusse, Goodnough, \& Noël, 2001b). school counselors assume a broad range of responsibilities, which include providing individual and group counseling, conducting psycho-educational outreach with a large student body, providing educational testing and academic advising, completing various administrative tasks, and engaging in clinical supervision to school counselor trainees, to name a few. Because of varied roles and heavy responsibilities, school counselors may be susceptible to experiencing burnout. Nevertheless, many researchers believed that burnout is related to self-efficacy. Those with low self-efficacy as indicated by Grau, Salanova and Peirò (2001) could experience high levels of occupational stress. In a study that investigates the association between perceived self-efficacy and burnout among teachers, Friedman (2003) found that self-efficacy correlated significantly with burnout. Teachers with low self-efficacy experience higher burnout. Similar finding was detected by Brouwers and Tomic (2000). For instance, they found that self-efficacy beliefs regarding classroom management were significantly related to levels of teacher burnout. Thus, if counselors posses a high level of self-efficacy, they can avoid having to experience burnout. Knowing counselors perceived self-efficacy helps the employers to identify more and less self-efficacious counselors, gauge improvements needed to improve counselors' self-efficacy, plan training program, as well as identifying counselors at risk for burnout and related workforce development needs.

The present study found that Malaysian school counselors possess a high level of self-efficacy, thus it is unlikely they will experience burnout. With such a high self-efficacy, Malaysian school counselors may be able to perform their duties and shoulder their responsibilities efficiently, thus will enable them to help secondary school students in their journey in career development. An examination of table 2 would indicate that there are some areas of the tasks that need to be improved by the counselors. For instance, they need to improve their ability in job market research, conducting career development activities, evaluate the nature of the job. The present study shows that regardless of gender, their levels of self-efficacy are similar. However, the present study shows that their self-efficacy differs as a function of level of education, work experience. It was found that those with graduate education possess a much higher level of self-efficacy compared to those with undergraduate degree. These two findings suggest that self-efficacy may be modified with years of experience and level of education. This is probably due to a more advance courses they go through while in graduate education. A study on teacher sense of efficacy by Moran and Hoy (2006) showed that experience is related to the sense of efficacy. This is similar to Bandura (1997) where mastery experience make the strongest contribution to self-efficacy belief. Counselors with experience tend to be more confident in performing their duties and compared to those with less experience. Potosky (2002) indicates that computer experience has been consistently reported to have positive relationship with career self-efficacy beliefs. Similarly, Hassan (2003) reported that computer experience was related to computer self-efficacy

Moreover, it is important for school counselors to have high level of self-efficacy due to the fact; the more confident you are in your job, the better you will function as a counselor. Thus, it is suggested that counselors should pursue their education at the postgraduate level. Engagement in professional development activities, such as taking continuing education courses and attending workshops related to needed areas of competence will increase feelings of work-related efficacy in their settings (Butler \& Constantine, 2005)

\section{References}

Bandura, A. (1986). Social foundations of thoughts and action: A social cognitive theory. Englewood Cliffs, NJ: Prentice Hall.

Bandura, A. (1989). Regulation of cognitive processes through perceived self-efficacy. Developmental Psychology, 25, 729-735. doi:10.1037/0012-1649.25.5.729, http://dx.doi.org/10.1037/0012-1649.25.5.729

Bandura, A. (1995). Exercise of personal and collective efficacy in changing societies. In A. Bandura (Ed.), Self-efficacy in changing societies. New York: Cambridge University Press. doi:10.1017/CBO9780511527692.003, http://dx.doi.org/10.1017/CBO9780511527692.003

Bandura, A. (1996). Ontological and epistemological terrains revisited. Journal of Behavior Therapy and Experimental Psychiatry, 27, 323-345. doi:10.1016/S0005-7916(96)00049-3, http://dx.doi.org/10.1016/S0005-7916(96)00049-3

Bandura, A. (1997). Self-efficacy: the exercise of control. New York: Freeman.

Bodenhorn, N., \& Skaggs, G. (2005). Development of the school counselor self-efficacy scale. Measurement and Evaluation in Counseling and Development, 38, 14-28. 
Bodenhorn, Nancy, Wolfe, Edward W., \& Airen, Osaro E. (2010). School counselor's programs choice and self-efficacy: Relationship achievement gap and equity. Professional School Counseling, Vol. 13 Issue 3, p165-174. doi:10.5330/PSC.n.2010-13.165, http://dx.doi.org/10.5330/PSC.n.2010-13.165

Brigman, G., \& Campbell, C. (2003). Helping students improve academic achievement and school success behavior. Professional School Counseling, 7, 91-98.

Brouwers, A., \& Tomic, W. (2000). A longitudinal study of teacher burnout and perceived self-efficacy in classroom management. Teaching and Teacher Education, 16(2), 239-253. doi:10.1016/S0742-051X(99)00057-8, http://dx.doi.org/10.1016/S0742-051X(99)00057-8

Butler, S. K., \& Constantine, M. G. (2005). Collective self-esteem and burnout in professional school counselors. Professional School Counseling, 9(1), 55-62.

Daniels, J. A., \& Larson, L. M. (2001). The impact of performance feedback on counseling self-efficacy and counselor anxiety. Counselor Education \& Supervision, 41, 120-130.

Diane M. Clark. (2006). School counselor self-efficacy as related to ASCA national model for school counselors. A dissertation submitted to the faculty of The University of North Carolina at Charlotte.

Fitch, T., Newby, E., Ballestero, V., \& Marshall, J. L. (2001). Future school administrators' perceptions of the school counselor's role. Counselor Education \& Supervision, 41, 89-99.

Fitch, T.J., \& Marshall, J.L. (2004). What counselors do in high-achieving schools: A study on the role of the school counselor? Professional School Counseling, 7, 172-177.

Friedman, I. A. (2003). Self-efficacy and burnout in teaching: the importance of interpersonal-relations efficacy. 6(3): 191-215

Gibson, S., \& Dembo, M.H. (1984). Teacher efficacy: a construct validation. Journal of Educational Psychology, 76, 569-582. doi:10.1037/0022-0663.76.4.569, http://dx.doi.org/10.1037/0022-0663.76.4.569

Grau, R., Salanova, M., \& Peirò, J.M. (2001). Moderator effects of self-efficacy on occupational stress. Psychology in Spain, 5(1), 63-74.

Hasan, B. (2003). The influence of specific computer experiences on computer self-efficacy. Computers in Human Behavior, 19(4), 443-450. doi:10.1016/S0747-5632(02)00079-1, http://dx.doi.org/10.1016/S0747-5632(02)00079-1

Heppner, M. J., O'Brien, K. M., Hinkelman, J. M., \& Flores, L. Y. (1996). Training ounseling psychologists in career development: Are we our own worst enemies? The Counseling Psychologist, 24, 105-125. doi:10.1177/0011000096241007, http://dx.doi.org/10.1177/0011000096241007

Herr, E. L., Cramer, S. H., \& Niles, S. G. (2004). Career guidance and counseling through the lifespan. Systematic approaches (6th Ed.). New York: Harper Collins.

Kuranz, M. (2002). Cultivating student potential. Professional School Counseling, 5, 172-179.

Lapan, R.T., Gysbers, N. C, \& Sun, Y. (1997). The impact of more fully implemented guidance programs on the school experiences of high school students: A statewide evaluation study. Journal of Counseling and Development, 75, 292-302.

Lapan, R.T., Gysbers, N.C., \& Petroski, G.F. (2001). Helping seventh graders be safe and successful: A statewide study of the impact of comprehensive guidance and counseling programs. Journal of Counseling and Development, 79, 320-330.

Larson, L. M. (1998). The social cognitive model of counselor training. The Counseling Psychologist, 26, 219-273. doi:10.1177/0011000098262002, http://dx.doi.org/10.1177/0011000098262002

Larson, L.M., \& Daniels, J.A. (1998). Review of counseling self-efficacy literature. Journal of Counseling Psychology, 26, 179-218. doi:10.1177/0011000098262001, http://dx.doi.org/10.1177/0011000098262001

Larson, L.M., Suzuki, L.A., Gilespie, K.N., Potenza, M.T., Bechtel, M.A., \& Toulouse, A.L. (1992). Development and validation of the counseling self-estimate inventory. Journal of Counseling Psychology, 39, 105-120. doi:10.1037/0022-0167.39.1.105, http://dx.doi.org/10.1037/0022-0167.39.1.105

Legum, H.L., \& Hoare, C.H. (2004). Impact of a career intervention on high-risk middle school students' career maturity levels, academic achievement, and self-esteem. Professional School Counseling, 8, 148-155.

Lent, R. W., \& Hackett G. (1987). Career self-efficacy: Empirical status and future directions. Journal of Vocational Behavior, 30.

Lent, R.W., Hill, C.E., \& Hoffman, M.A. (2003). Development and validation of the counselor activity self-efficacy scales. Journal of Counseling Psychology, 50(1), 97-108. doi:10.1037/0022-0167.50.1.97, http://dx.doi.org/10.1037/0022-0167.50.1.97

Melchert, T.P., Hays, V.L., Wiljanen, L., \& Kolocek, A. (1996). Testing models of counselor development with a measure of counseling self-efficacy. Journal of Counseling and Development, 74(6), 640-644. 
Moran, M. T \& Hoy, A. W. (2007). The differential antecedent of self-efficacy beliefs of novice and experienced teachers. Teaching and Teacher Education, 23(6), 944-956. doi:10.1016/j.tate.2006.05.003, http://dx.doi.org/10.1016/j.tate.2006.05.003

Niles, S. G., \& Karajic, A. (2008). Training career practitioners in the 21 st century. In J. A. Athanasou \& R. van Esbroeck (Eds.). International handbook of career guidance (pp. 355- 374). doi:10.1007/978-1-4020-6230-8_18, http://dx.doi.org/10.1007/978-1-4020-6230-8_18

Pérusse, R., Goodnough, G. E., \& Noël, C. J. (2001b). Use of the national standards for school counseling programs in preparing school counselors. Professional School Counseling, 5, 49-55.

Potosky, D. (2002). A field study of computer self-efficacy beliefs as an outcome of training: the role of computer playfulness, computer knowledge, and performance during training. Computers in Human Behavior, 18(3), 241-255. doi:10.1016/S0747-5632(01)00050-4, http://dx.doi.org/10.1016/S0747-5632(01)00050-4

Sink C.A., \& Stroh, H.R. (2003). Raising achievement test scores of early elementary students through comprehensive school counseling programs. Professional School Counseling, 6, 350-364.

Steen, S., \& Kaffenberger, C.J. (2007). Integrating academic interventions into small group counseling in elementary school. Professional School Counseling, 10, 516-519.

Webb, L.D., Brigman, G., \& Campbell, C. (2005). Linking school counselors and student success: A replication of the student success skills approach targeting academic social competence of students. Professional School Counseling, 8, 407-413.

Table 1. Means and Standard Deviations of Counselors" Self-Efficacy by Level of Education, Area of Studies, and Gender

\begin{tabular}{|c|c|c|c|c|c|}
\hline & Academic Qualification & $\mathrm{N}$ & Mean & Std. Dev. & Test \\
\hline \multirow[t]{3}{*}{ MINEFFICACY } & Post graduate degree & 70 & 4.18 & .54 & $\mathrm{~T}(420)=3.19, \mathrm{p}=.002$ \\
\hline & Bachelor's degree & 361 & 3.94 & .58 & \\
\hline & Area of study & & & & \\
\hline \multirow[t]{3}{*}{ MINEFFICACY } & Guidance \& Counseling & 335 & 3.99 & .54 & $\mathrm{~T}(405)=-.109 ; \mathrm{p}=.91$ \\
\hline & Others & 72 & 3.99 & .67 & \\
\hline & Gender & & & & \\
\hline \multirow[t]{2}{*}{ MINEFFICACY } & Male & 193 & 4.03 & .53 & $\mathrm{~T}(437)=1.61 ; \mathrm{p}=0.11$ \\
\hline & Female & 246 & 3.94 & .62 & \\
\hline
\end{tabular}


Table 2. Means and standard deviations of counselors' self-efficacy

\begin{tabular}{|c|c|c|}
\hline Self-Efficacy Indicators & Mean & SD \\
\hline Use theory, strategy and consultation models in giving career counseling to students & 3.71 & 0.88 \\
\hline Cooperate with other teachers to identify students' interest & 3.99 & 0.82 \\
\hline $\begin{array}{l}\text { Use the right career counseling technique appropriate with students' objectives, needs, } \\
\text { psychological criterion and work development level }\end{array}$ & 3.99 & 0.72 \\
\hline Identity students character & 4.03 & 0.69 \\
\hline $\begin{array}{l}\text { Identify situational context that influence students' choices of courses in higher learning } \\
\text { institution }\end{array}$ & 4.07 & 0.71 \\
\hline $\begin{array}{l}\text { Act as an advisor in assisting students to choose the appropriate program in higher } \\
\text { learning institution }\end{array}$ & 4.14 & 0.79 \\
\hline Assist students with education and career decision making process & 4.21 & 0.70 \\
\hline Relate students personality with their education and career choices & 4.18 & 0.71 \\
\hline Organize school career day & 3.97 & 0.91 \\
\hline Help students choose the right course to pursue studies & 4.17 & 0.69 \\
\hline Cooperate with other teachers to identify students' ability & 3.99 & 0.82 \\
\hline Cooperate with certain institutions in organizing career development programs in schools & 4.11 & 0.76 \\
\hline Promote career development activity to students & 3.87 & 0.85 \\
\hline Act as a mentor in guiding students to choose programs in tertiary level & 3.91 & 0.82 \\
\hline Analyze the need of job market in future & 3.67 & 0.89 \\
\hline Relate the need of job market in future with & 3.89 & 0.82 \\
\hline Assist students to translate evaluation data & 3.90 & 0.83 \\
\hline $\begin{array}{l}\text { Assist students in making the right choices of educational programs in higher learning } \\
\text { institutions based on evaluation results }\end{array}$ & 4.02 & 0.79 \\
\hline Gain information regarding career and educational program using computer system & 3.76 & 0.94 \\
\hline $\begin{array}{l}\text { Gain information regarding educational programs and career preparation without having to } \\
\text { depend on computer system }\end{array}$ & 3.65 & 0.94 \\
\hline Plan career development program at school level & 4.00 & 0.78 \\
\hline Carry out career development activity in school & 3.96 & 0.79 \\
\hline $\begin{array}{l}\text { Plan, organize and manage all useful sources to help students to make education and career } \\
\text { decision }\end{array}$ & 3.95 & 0.78 \\
\hline Assist students in identifying their goals and objectives & 4.28 & 0.66 \\
\hline Help students to get the skills of choosing suitable career for them & 4.21 & 0.71 \\
\hline Encourage students to look into various factors before choosing a career & 4.32 & 0.67 \\
\hline Help students to make career choice based on evaluation results & 4.12 & 0.77 \\
\hline $\begin{array}{l}\text { Evaluate work place situation such as sense of duty, higher management's expectations, } \\
\text { norms and job qualities }\end{array}$ & 3.87 & 0.77 \\
\hline Make an accurate report of evaluation students' evaluation & 3.71 & 0.83 \\
\hline Evaluate data obtained from evaluation form & 3.85 & 0.81 \\
\hline Make decision based on the evaluation done towards students & 3.90 & 0.80 \\
\hline Organize and report the results of career evaluation & 3.83 & 0.81 \\
\hline Assist students in obtaining various careers related information & 4.35 & 0.67 \\
\hline Evaluate students personality such as capability, achievement, interest, and personal values & 4.17 & 0.75 \\
\hline Overall Mean & 3.98 & 0.59 \\
\hline
\end{tabular}

Reliability estimate $=.96$ 